\title{
Medical Undergraduate Students Response of Learning Process Using Drawing and Animation Videos
}

\author{
Aisyah Elliyanti ${ }^{1,2^{*}}$ Dian Pertiwi ${ }^{3}$
}

\author{
${ }^{1}$ Faculty of Medicine, Universitas Andalas, Medical Physics Department, Kampus Limau Manis Fakultas Kedokteran, \\ Padang, Indonesia 25163 \\ ${ }^{2}$ Nuclear Medicine Division of Radiology Department, Dr.M.Djamil Hospital, Padang, Indonesia \\ ${ }^{3}$ Faculty of Medicine, Universitas Andalas, Clinical Pathology Department, Padang, Indonesia 25163 \\ *Corresponding author. Email: aelliyanti@med.unand.ac.id
}

\begin{abstract}
This study aimed to determine students' perceptions of understanding learning material using the drawing method. Ten undergraduate medical students participated in creating cardiovascular material based on their topic of discussion. The materials convert to animation videos. Thirty-eight students participate in the survey to assess their perception of video material. $65.8 \%$ of respondents mention weekly reports are needed, and they like it is submitted in text and PowerPoint format. $84.2 \%$ of respondents agree with a drawing as report format increased their understanding. After watching the video, respondents agree that the video increases the understanding $92 \%$, and $5.3 \%$ and $2.6 \%$ mention do not know and not answer (missing), respectively. Even though the respondents prefer to attend teaching classes, respondents are more likely knowledge deliver using drawing/animation, video, and chart, which is more interesting.
\end{abstract}

Keywords: Learning style, understanding, electronic learning sources, recall of knowledge

\section{INTRODUCTION}

Problem-based learning (PBL) is advocating experience- based education. The problems trigger students to search for knowledge, concepts, and strategies to solve the problems [1]. In PBL, students learn by solving problems and reflecting on their experiences. PBL is perfect for helping students become active learners because it puts learning into real-world problems and makes students responsible for their learning. The condition helps students develop strategies and build knowledge. Furthermore, the PBL method invites students to have the ability to think flexibly and learn for life, which is a necessity for a doctor $[1,2]$.

Tutorials are at the heart of PBL activities. The tutorial is a small group discussion consisting of a maximum of 10 students facilitated by a tutor, scheduled twice a week, for five weeks/block using the seven jumps method. In the first discussion, the students discussed a problem scenario to get the module's learning objectives to solve problems in the scenario. The second discussion contains discussion activities based on the learning objectives that have been set in the previous discussion. The students build their knowledge from problems learning material that it reflects during the tutorial discussion. They are guided to organizing all information and develop their meta-cognitive to solve a problem. [1] Thus, at the end of the block, students are expected to have a thinking order (cognitive restructuring) to shape professional behavior (professional behavior). At the end of the tutorial, Students submit their discussion report to evaluate the students learning process or selfdirected learning. [2] Lecturers/facilitators of te n v oice about our medical undergraduate is low long-term knowledge retention. It can be caused by the knowledge acquired through PBL being less organized than through conventional learning methods. [3] When they meet students' professional stage, some voices have weaknesses in basic medical science. [4]

It has long been known that drawing helps a person remember the details, and organized it to be drawn. One study reported that drawing is superior to reading or writing activities. To produce a drawing, people force to process information in various ways: visually, kinesthetic, and semantically $[5,6]$. 
The researchers found that the information conveyed by drawing to be a powerful way to improve memory, almost doubling memory. Myra Fernandes, Jeffrey Wammes, and Melissa Meade studied how activities such as writing, viewing pictures, listening to lectures, drawing, and visualizing pictures affect students' memorized the information. They found drawing to be "an effective and reliable strategy, and far superior to writing." The experts reported that when the students visually represented science concepts, their recall was nearly twice as good as when they wrote down definitions supplied by the lecturer [7]. Empirical evidence suggests that drawing can enhance understanding at an advanced rather than an elementary level, with the theoretical assumption that drawing leads to mental models' construction [5,6]. This study reports students' perception of learning content material in improving understanding of a concept during the tutorial process.

Students developed image-based learning (a pilot project) as a report after the second tutorial discussion. We convert to a video with images. To produce an image, the student must understand the material well. Thus, it is hoped that it can increase students' understanding of a material that can continue to be carried until they reach the professional stage. Furthermore, to answer the challenges of the education electronic-based 4.0 , the video of the final discussion report made by students can be stored electronically in the cloud and can be played back at any time wherever they need it.

\section{METHODS}

This research design is a cross-sectional study by observing students' perception of drawing/animation material built from their learning process.

\subsection{Participants}

Ten undergraduate medical students in the fourth semester of the Medical Faculty, Universitas Andalas, namely group \#4A, participated in creating the learning material. They are in the same class of cardiovascular tutorial using seven jumps method; step 1: clarify the unfamiliar term, 2: define the problems, 3: brainstorm possible hypothesis, 4: arrange explanation into tentative solution, 5: Defining learning objective, 6: information gathering, 7: a synthesis. After step 5 students encourage to use drawing or schema to explain the pathogenesis process for step 6 and 7 discussions.

\subsection{Learning material}

At the end of the tutorial discussion, students have to submit their discussion report by constructing learning material based on their learning objectives using illustration/pictures beside the text to explain the disease pathogenesis concepts.

\subsection{Create an animation of learning material}

The discussion materials produced by students were sent to the animator specialist. The animator produced the video based-on learning material that was submitted by students. The cardiology expert assessed the learning content before it uploaded to the Youtube channel of the Faculty of Medicine, Universitas Andalas.

\subsection{Experimental Measures}

Thirty-eight students are involved as respondents in a review of the learning material using an electronic form. It fulfilled after students watched the learning video that uploaded. Students give their opinion about their understanding of learning material after watching the video.

\section{RESULTS AND DISCUSSION}

Videos are sent to the expert/ cardiologist for a detailed review of the content. The expert gave an excellent comment about the student's understanding of the material. The characteristic of students and their opinion about the video shown in table 1 .

Table 1. Students characteristic and opinions

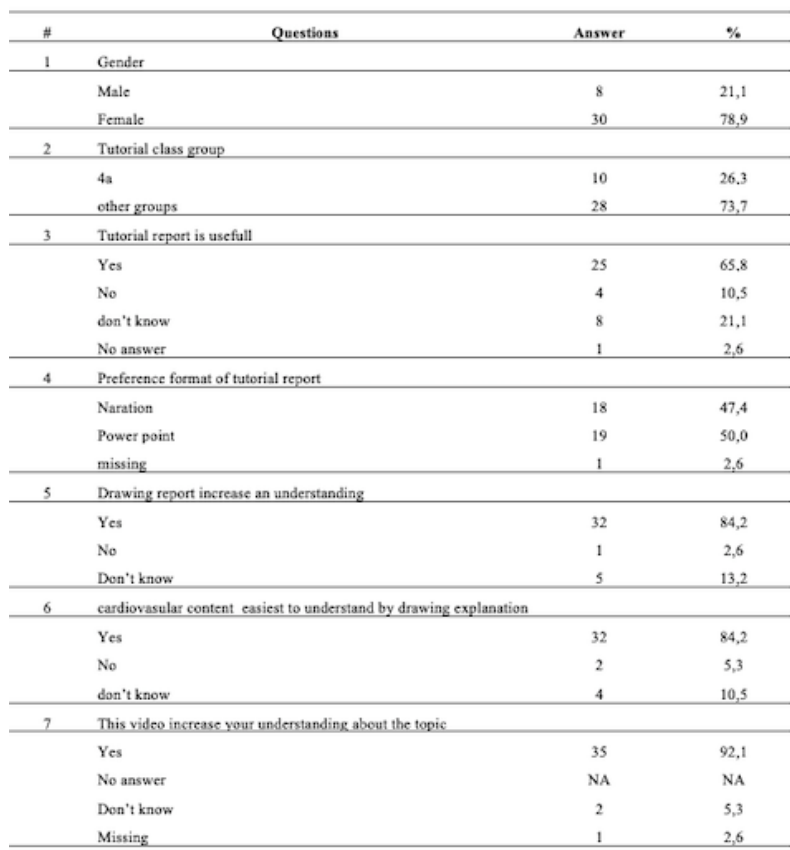

The number of female students given a response more than males. The condition can be due to the number of female students three times that of males. Other studies also report female numbers increasing in medical school $[8,9,10]$. 
Students response to the weekly report was $65.8 \%$ of them mention the reports after the second discussion are needed, and they like the report both in text and PowerPoint format. Interestingly $84.2 \%$ of respondents agree on a drawing as report format. It increased their understanding of the content. They also agreed that block content is more preferable to be understood by drawing than narration. After watching the video, students agree that the video increase understanding by $92 \%, 5.3 \%$ mention do not know and $2.6 \%$ and not answer (missing). In this study, the students were interested in attending the teaching class, $44.7 \%$ compared to discussion and project $28.9 \%, 15.8 \%$, respectively, as shown in table 2. Furthermore, respondents are more likely its deliver by drawing/animation, video, and chart shown in table 3 . Ten students are involved in creating learning material mentioned the tasks increased their understanding of the material because they have to gather all information and build their concept to explain the context in drawing reports.

Table 2. Students Preference of learning method

\begin{tabular}{ccc}
\hline \multicolumn{1}{c}{ Level of interesting } & Answers \\
\hline & learning by discussion of the topic \\
\hline 1 & & 8 \\
2 & & 19 \\
3 & & 11 \\
\hline & attending of a teaching class \\
\hline 1 & & 1 \\
3 & & 18 \\
\hline & & 17 \\
\hline 1 & Joint the project based learning \\
2 & & 20 \\
3 & & 12 \\
& & 6 \\
& &
\end{tabular}

Table 3. Students opinions about interesting of learning process

\begin{tabular}{ll}
\hline$\#$ & Learning methods are interesting \\
\hline 1 & Drawing /Video with good animation \\
2 & Charts \\
3 & Teaching Class \\
4 & Self learning \\
5 & Solving case \\
6 & Trivia \\
\hline
\end{tabular}

To encourage active learning and increase student interaction in constructing their knowledge, it can apply by using concept drawing, which is briefly annotated with processes, concepts, and their relationship to one and another. When the lecturer draws the concept, knowledge delivers more easiest to understand by students. Students can then create their concept after viewing detailed animation, video clips, photos, and textbook, and explaining it to their peers. Students need to process full information, consolidate their understanding, and personalize the information to suit their learning style. In this way, the learning process promotes better student understanding of the systems and enables students to use the knowledge better to follow the processes and underlying principles [11].

To promotes students understanding and consolidate the concept, a drawing can be one of the choices. The drawing method applied in anatomy class between 2012 to 2014 has led to better results as reported by Joewono et al. The drawing retains the same way, the same time, and the same assessment. The class variety is more attractive and practical for students in learning anatomy. Drawing methods that can increase cut-off student test results in the Medical Faculty of Udayana University.[12]

Drawing is a visual learning style. Ibrahim and Hussein's study reported that students prefer a visual style because it is more accessible and attractive. Furthermore, they found a different preference for learning styles between male and female students. Male prefer a visual, kinesthetic, and auditory learning style while women prefer visual, auditory, and kinesthetic. The number of female students is higher in our school, which can also have shown a tendency to learn from visual and auditory systems. The drawing process tends to kinesthetic and visual than auditory because the drawing process involves exploration, coordination, and understanding. A drawing method suitable for every learning style. A better understanding, ideas, and knowledge are required to produce a drawing. By drawing, students can explain concepts in science and can be used to explain the idea to peers and the community $[4,12]$.

\section{CONCLUSION}

Even though the respondents prefer to attend teaching class, respondents are more likely the content delivered using drawing/animation, video, and chart, which is more interesting. Furthermore, a tutorial report in drawing increases their understanding of the learning material. Further study needs to elaborate on the drawing effect to increase the knowledge retention of students.

\section{ACKNOWLEDGMENT}

This work was supported by Lembaga Pengembangan Pembelajaran dan Penjaminan Mutu Universitas Andalas. Contract \# T.03/UN.16.18/PT.01.03/2020.

Thanks to Hadisty Fauziah Yenri, Claudia Novi Wijaya, Salsabila Revitan, Mohammad Rafiequl Hariry, Intania Dwiputri Hendriani, Yasmina Shofi Aningdia Adiba, Wira Dhika Tri Wulandari, Siti Salsabila Amri, Putri Afisia Gusman, Tiara Astriani Livia for participate in this study. 


\section{REFERENCES}

[1] Hmelo-Silver CE, Problem-Based Learning: What and How Do Students Learn?, Educational Psychology Review, Springer, 2004,vol 16,pp235266.

[2] Yew Elaine HJ, Goh Karen, Problem-Based Learning: An Overview of its Process and Impact on Learning. Health Professions Education. Elsevier, 2016, Vol 2,pp.75-79.

DOI:https://doi.org/10.1016/j.hpe.2016.01.004

[3] Ahmad Abdelkarim., et al. "Advantages and Disadvantages of Problem-Based Learning from the Professional Perspective of Medical and Dental Faculty". EC Dental Science 17.7 (2018).

[4] Van Meter P, Aleksic M, Schwartz A, Garner J, Learner-generated drawing as a strategy for learning form content area text, Contemporary Educational Psychology, Elsevier, 2006, Vol 31, pp. 142-166. doi:10.1016/j.cedpsych.2005.04.001

[5] Van Meter P, Drawing construction as a strategy for learning form content text, Journal of Educational Psychology, 2001, Vol 93, pp. 129-140

[6] Terada Y, The Science of Drawing and Memory, 2019 ttps://www.edutopia.org/article/sciencedrawing-and-memory
[7] Shankar P, Singh K, Singh S. Possible impact of increase in female medical student admissions in Nepal: Findings from a qualitative study among medical undergraduates. Australas Med J. 2012;5(3):184-193. doi:10.4066/AMJ.2011.1187

[8] McKinstry B. Are there too many female medical graduates? Yes. BMJ. 2008;336(7647):748. doi:10.1136/bmj.39505.491065.94

[9] Glauser W. Rise of women in medicine not matched by leadership roles [published correction appears in CMAJ. 2018 Aug 7;190(31):E942]. CMAJ. 2018;190(15):E479-E480. doi:10.1503/cmaj.109-5567

[10] Johnson JK, Reynolds SJ, Concept Sketches - Using Student- and Instructor-generated, Annotated Sketches for Learning, Teaching, and Assessment in Geology Courses. Journal of Geoscience, 2005, Vol 52,pp.85095. doi: 10.5408/1089-9995-53.1.85

[11] Joewono M, Karmaya NM, Wirata G, Yuliana, Widianti IGA, Wardana ING, Drawing method can improve musculoskeletal anatomy comprehension in medical faculty student, Anatomy and Cell Biology,2018,vol 51,pp.14-18.

DOI: $10.5115 / \mathrm{acb} .2018 .51 .1 .14$

[12] Ibrahim RH, Hussein DA. Assessment of visual, auditory, and kinesthetic learning style among undergraduate nursing stu- dents. Int J Adv Nurs Stud 2016, Vol 5, pp. 1-4. doi: 10.14419/ijans.v5i1.5124 